Dobrawa Lisak-Gębala

\title{
Polska eseistyka o malarstwie i fotografii od 2. połowy XX wieku w świetle rozważań nad esejem jako formą (pisarstwa, poznania, doświadczania...) $)^{1}$
}

\begin{abstract}
Lisak-Gębala Dobrawa, Polska eseistyka o malarstwie i fotografii od 2. połowy XX wieku w świetle rozważań nad esejem jako formą (pisarstwa, poznania, doświadczania...) [Polish essays on painting and photography from the $2^{\text {nd }}$ half of the $20^{\text {th }}$ century in the light of reflections on the essay as a form (of writing, cognition, and experiencing)]. „Przestrzenie Teorii” 22. Poznań 2014, Adam Mickiewicz University Press, pp. 55-69. ISBN 978-83-232-2827-1. ISSN 1644-6763.

Contemporary Polish essays on paintings and photographs (by, e.g. Z. Herbert, G. Herling-Grudziński, W. Karpiński, J. Pollakówna, E. Bieńkowska, A. Olędzka-Frybesowa, and W. Nowicki) are juxtaposed with the personal essay which was invented by Montaigne. A wide range of commentaries, including ideas about this genre which were expressed by Th. W. Adorno, G. Lukács, and G. Douglas Atkins, provide a theoretical background for the analysis. Selected Polish texts are presented as artistic constructions that recreate the process of experiencing pictures and the movement of thoughts of the essayistic "self" which uses many disguises (e.g. a traveler, amateur, scholar and critic). A particular painting or photo, which is often artfully described by means of ekphrasis, is treated by essayists as a starting point for analyzing many broader issues as well as for indirect self-presentation.
\end{abstract}

Niejednokrotnie już przestrzegano przed próbami wydzielania z pola eseistyki pododmian, szczególnie tych wyprowadzanych ze względu na kryterium tematyczne ${ }^{2}$. Podejmowane od czasu do czasu przedsięwzięcia typologiczne, jakby na potwierdzenie tych obiekcji, wieńczone bywają na ogół konstatacją, iż niełatwo jest odnaleźć „czyste” przykłady wyodrębnionych wariantów, gdyż esej z natury swojej okazuje się tworem proteuszowym, zręcznie manewrującym pomiędzy różnorakimi zagadnieniami, konwencjami wypowiedzi, kreacjami podmiotu etc. Przy zamiarze opisania eseistyki „o malarstwie i fotografii” nie sposób więc uciec od wy-

1 Projekt został sfinansowany ze środków Narodowego Centrum Nauki przyznanych na podstawie decyzji numer DEC-2011/01/N/HS2/00510.

2 Np. K. Dybciak, Inwazja eseju, „Pamiętnik Literacki” 1977, z. 4, s. 118; A. Zawadzki, Nowoczesna eseistyka filozoficzna $w$ piśmiennictwie polskim pierwszej połowy XX wieku, Kraków 2001, s. 6; R. Sendyka, Nowoczesny esej. Studium historycznej świadomości gatunku, Kraków 2003, s. 171, przypis 37; C.H. Claus, Toward a collective poetics of essay, [w:] Essayists on the Essay. Montaigne to Our Time, ed. C.H. Claus, N. Stuckey-French, Iowa City 2012, s. XXII. 
jaśnienia, jak owo zaanonsowane kryterium - nieuchronnie kojarzące się przecież $\mathrm{z}$ kryterium stricte tematycznym - będzie w praktyce funkcjonowało przy doborze materiału do analizy. Nie sposób również uniknąć odpowiedzi na pytanie, jak rozumiany będzie sam nadrzędny termin „eseistyka”. I właśnie między tymi dwiema skalami - mikro i makro - wytyczone zostanie pole refleksji; bez pośredniego przejścia poprzez domniemaną subodmianę gatunkową.

Odnosząc się do pierwszej skali (mikro), należy stwierdzić, iż fraza „eseje o malarstwie i fotografii” mogłaby w praktyce zostać rozwinięta do postaci „eseje o konkretnych dziełach malarskich i fotografiach”, w polu zainteresowania umieszczone zostaną bowiem wyłącznie teksty, w których występują odniesienia do poszczególnych obrazów, często realizowane jako ekfrazy3 ${ }^{3}$ nie zaś takie, które in abstracto rozważają naturę medium. Zawężenie obszaru jest zabiegiem celowym, gdyż zajmuje mnie przede wszystkim kwestia, jak funkcjonuje obraz (lub zbiór obrazów) usytuowany na istotnej dla form eseistycznych pozycji konkretu - stymulującego łańcuch doświadczeń i refleksji, włączanego w samopoznanie „ja”, stającego się katalizatorem wielopostaciowej narracji, misternie wplatanym w tkankę tekstu. Stąd dzieła malarskie i fotografie bardziej niż tematem okazują się punktem wyjścia (Lukácsowskim „początkiem, odskocznią"4) lub jednym z przystanków typowo eseistycznej wędrówki między licznymi zagadnieniami. Takie podejście pozwala uwzględnić teksty o różnorakiej nadrzędnej ramie narracyjnej (bywa nią przykładowo relacja z podróży, portret miasta, opowieść o malarzu), które jawią się jako wielotematyczne.

3 Pionierskim omówieniem tego typu tekstów jest artykuł R. Sendyki Esej i ekfraza (Herbert - Bieńkowska - Bieńczyk), „Przestrzenie Teorii” 2009, nr 11. Najbardziej reprezentatywne przykłady interesujących mnie esejów odnaleźć można w tomach Zbigniewa Herberta (Barbarzyńca w ogrodzie - 1962; Martwa natura $z$ wędzidtem - 1993), Jarosława Iwaszkiewicza (Podróże do Włoch - 1977), Gustawa Herlinga-Grudzińskiego (Sześć medalionów i srebrna szkatułka - 1994), Józefa Czapskiego (Patrzac - 1983), Konstantego Aleksandra Jeleńskiego (Zbiegi okoliczności - 1982), Wojciecha Karpińskiego (np. Pamięć Włoch - 1982, Fajka Van Gogha - 1995, Portret Czapskiego - 2007), Aleksandry Olędzkiej-Frybesowej (m.in. Lustra, znaki i obrazy - 2000), Joanny Pollakówny (Myślac o obrazach - 1994, Glina i światto - 1999, Weneckie tęsknoty - 2003), Ewy Bieńkowskiej (Co mówia kamienie Wenecji - 1999), Witolda Zalewskiego (Zwiadowcy światła - 1999), Wojciecha Nowickiego (Dno oka. Eseje o fotografii - 2010). Fotoplastikon Jacka Dehnela (2009) traktować można jako zjawisko komplementarne: przykład zeseizowanych ekfraz. Interesującym przypadkiem wyróżnionej eseistyki jest Obrona Van Meegerena Kazimierza Wyki („Odrodzenie” 1947, nr 21) - tekst niezawierający ekfraz.

${ }^{4}$ G. Lukács, O istocie $i$ formie eseju. List do Leo Poppera, przeł. R. Turczyn, [w:] Pisma krytyczno-teoretyczne Georga Lukácsa. 1908-1932, wybór i wstęp S. Morawski, Warszawa 1994, s. 91. 
Wypowiedzi, którym przypisuje się miano eseistyki o sztukach wizualnych, to obszar niezmiernie pojemny i zróżnicowany, obejmujący zarówno tak zwane eseje literackie, jak i „eseizowane” - swobodniejsze, atrakcyjnie napisane teksty o charakterze naukowym lub krytycznoartystycznym, często określane jako „szkice”. W rozpatrywanym obszarze praktyki wydawnicze, nagrody literackie dodatkowo wprowadzają dość swobodne demarkacje genologiczne. Rozgraniczenie esej - szkic jest zdecydowanie chwiejne, gdyż często określenia te traktowane są wymiennie (tendencja ta ujawnia się nawet $\mathrm{w}$ podtytułach zbiorów oraz $\mathrm{w}$ towarzyszących tym publikacjom odautorskich komentarzach - często wymiennie traktuje się terminy „esej” i „szkic literacki”)5. Można wszakże wskazać liczne wypowiedzi metaeseistyczne, w których nawoływano, by nie utożsamiać eseju ze szkicem (m.in. Maxa Bensego, Krzysztofa Dybciaka, Małgorzaty Krakowiak ${ }^{6}$ ) bądź z parergonem (Lukács). Opowiadam się za ujęciem, podług którego szkic byłby formą mniej zobowiązującą zarówno pod względem konstrukcji tekstu, jak i doniosłości myślowej, często zależną od konwencji takich dziedzin jak nauka czy krytyka artystyczna, i w tych przypadkach ciążącą ku przewidywalnej, monotematycznej strukturze narracji ${ }^{7}$.

Eseizacja, wkraczająca w teksty badaczy humanistów, obserwowana jest również $\mathrm{w}$ dziedzinie literatury faktu (np. podróżopisarstwa) i literatury dokumentu osobistego (np. diarystyki). Genus proximum wszystkich wymienionych powyżej form, z którymi esej się styka i osmotycznie wymienia właściwości, to nader pojemny obszar prozy niefikcjonalnej, a przecież istnieje wielowiekowa tradycja specyficznego i nierzadko bardzo wymagającego traktowania eseju, rozpoczynająca się od autotematycznych komentarzy w Próbach Montaigne'a. O zaawansowanej świadomości gatunkowej eseistów różnych epok i narodowości świadczyć może wydana w 2012 roku antologia Essayists on the Essay. Mimo długiej już tradycji polskiej eseistyki i bujnego rozkwitu tego kręgu pisarstwa odnotowywanego od czasów poodwilżowych ${ }^{8}$, w całej plejadzie autorów, któ-

5 Podtytuł „eseje” nosi wyłącznie zbiór W. Nowickiego, w odautorskich komentarzach swe teksty nazywają tak Pollakówna i Olędzka-Frybesowa. Herbert określa Barbarzyńce w ogrodzie jako „szkice”, ponadto Martwa natura $z$ wędzidtem zawiera część „Szkice” (choć w wersji angielskiej, która wyprzedziła pierwsze wydanie polskie, tenże dział nosił tytuł Essays, nie Sketches).

${ }^{6}$ M. Krakowiak (Mierzenie się z esejem. Studia nad polskimi badaniami eseju literackiego, Katowice 2013, s. 134) traktuje szkic jako pojęcie bardziej pojemne, nadrzędne wobec elitarnie rozumianego eseju.

7 Jako eseizowane szkice postrzegać można np. pisarstwo Mieczysława Porębskiego i Marii Poprzęckiej.

${ }^{8}$ Zob. R. Sendyka, Nowoczesny esej..., s. 142-142, 160; M. Krakowiak, dz. cyt., s. 64, 77-78. Przyjęta cezura chronologiczna odnosi się do poodwilżowego boomu eseistycznego, 
rych twórczość pasuje do ideału eseju, niewielu znalazło się takich, którzy bezpośrednio i obszerniej wypowiedzieli się na temat tej formy. Ogólne komentarze rozwinięte zostały przez Jerzego Stempowskiego, Karola Irzykowskiego (Benjaminek - 1933), Tadeusza Brezę, Bolesława Micińskiego i Jolantę Brach-Czainę, jak również przez dwoje autorów z kręgu eseistów piszących m.in. o malarstwie: Kazimierza Wykę, Ewę Bieńkowską, ponadto - skrótowo - przez Gustawa Herlinga-Grudzińskiego9. Tym bardziej na wyszczególnienie zasługują uwagi Aleksandry Olędzkiej-Frybesowej, która w tekście Od kapitelów z Cluny do batkańskiego choro sformułowała zalążek jedynego bodaj na gruncie polskiej eseistyki dotyczącej sztuk wizualnych programowego „eseju o eseju”:

Eseista jest niby harcownik dawnych batalii. W zdobywczej wyprawie, jaką szukający umysł podejmuje na tereny nieznane czy niezrozumiałe, jego działanie jest wstępnym elementem do dalszej akcji: pierwszym, nie całkiem zobowiązującym zetknięciem poznającego i poznawanego.

Albo też (pozostając wciąż w kręgu militarnej metaforyki, tak głęboko i tak fatalnie kształtującej nasze wyobrażenia, również w sferze pojęć) jest jak zwiadowca. Przynosi wiadomości, ale są one niepełne i subiektywne. Cząstkowość i stronniczość ujęć eseistycznych jest oczywista. Można i trzeba traktować ją wyłącznie jako propozycje następnych, naukowo już podejmowanych, badań, jako tymczasowe i zastępcze (czasem mimo wszystko - potrzebne) próby zbliżenia. Etymologicznie esej przecież to właśnie oznacza ${ }^{10}$.

Mogłoby się zdawać, że w tej podszytej krytyką definicji pobrzmiewa potraktowana serio, a zdeprecjonowana przez Bensego, idea eseju jako parergonu poprzedzającego uporządkowany system. Olędzka-Frybesowa toczy tu jednak ironiczną grę, i to w dodatku grę intertekstualną, fundującą swoisty palimpsest polskiej świadomości gatunku, nie sposób bowiem zlekceważyć nawiązania do metaeseistycznych rozważań Wyki z 1947 roku, gdzie krytyk zamieścił obszerną, ironiczną metaforę eseju jako „zwiadu na wojnie”. Kontynuując tę strategię, autorka w finale odwraca sensy i stwierdza: „Sztuka jest również formą poznania”, a teza ta,

kiedy to wydano m.in. Barbarzyńcę $w$ ogrodzie Herberta (1962), a ów tom ze względu na intensywną recepcję traktować można jako tekst założycielski tego nurtu powojennego eseistycznego podróżopisarstwa, w którym jednym z głównych tematów stanie się malarstwo. Jednocześnie początek drugiej połowy XX wieku to moment ukształtowania się środowiska emigracyjnego, z którego wywodzi się część omawianych tu autorów, związanych głównie ze środowiskiem „Kultury”. Paryskie wydanie Oka Czapskiego z 1960 r. wpisuje się zresztą w diagnozowany boom eseistyczny.

9 K. Wyka, Porozmawiajmy o essayu, „Odrodzenie” 1947, nr 29; E. Bieńkowska, Sztuka eseju, „Znak” 1976, nr 1; G. Herling-Grudziński, W. Bolecki, Rozmowy w Dragonei, Warszawa 1997, s. 306.

10 A. Olędzka-Frybesowa, Patrzq̨c na ikony, Warszawa 2001, s. 272. 
początkowo odniesiona do sztuki bizantyjskiej, przekształca się następnie w charakterystykę samego eseju jako poznania, które jest „kontemplacją, szerszą od pracy myślowej i ogarniającą całego człowieka, tj. poczuciem wspólnoty z tym, co poznawane", przeciwstawionego, opisanemu wcześniej przy użyciu metaforyki militarnej, „zubożonemu” poznaniu, „które daje panowanie nad światem"11. W tym kontekście niepewny swego, subiektywny esej jawi się jako antyscjentystyczny, bliski „poznaniu” artystycznemu, angażującemu pełnię człowieczeństwa. Ujawnia się tu zatem zaawansowana świadomość gatunkowa wraz z typową dlań wizją wyjątkowych zobowiązań i przywilejów eseju, od której nie stroni również naukowa refleksja o eseju ${ }^{12}$.

W kontekście próby opisu współczesnej polskiej eseistyki, w której pojawia się nawiązanie do malowideł i fotografii, atrakcyjny okazuje się właśnie idealny projekt eseju, „prawdziwego” eseju - jakby chciało się go określić, genuine essay (eseju „rasowego”, „czystej krwi”) - jak często nazywa się go współcześnie w kręgu anglosaskim, dlatego w szczególności pragnęłabym wyróżnić maksymalistyczne w swej wymowie postulaty: m.in. te wzięte z modernistycznych „esejów o eseju” (Theodora W. Adorna, Györgya Lukácsa, Virginii Woolf ${ }^{13}$ ), jak również zaczerpnięte z wypowiedzi młodszych obrońców czystości eseju zza oceanu, kontynuujących elitarny sposób postrzegania gatunku - szczególnie od G. Douglasa Atkinsa ${ }^{14}$. Ze względu na wspólną wymienionym komentatorom tezę, iż dominującym modelem współczesnej eseistyki jest model Montaigne’owski, Próby pojawiać się będą jako wzorcowa realizacja gatunku. Wyod-

11 Tamże, s. 281.

12 Warto dodatkowo wyróżnić studia: W. Głowala, Próba teorii eseju literackiego, [w:] Genologia polska, red. E. Miodońska-Brookes, A. Kulawik i M. Tatara, Warszawa 1983; A.S. Kowalczyk, Kryzys świadomości europejskiej w eseistyce polskiej lat 1945-1977 (Vincenz - Stempowski - Miłosz), Warszawa 1990; Polski esej. Studia, red. M. Wyka, Kraków 1991; oraz hasła słownikowe: D. Heck, Esej, [w:] Słownik literatury polskiej XX wieku, red. A. Brodzka i in., Wrocław 1992; A.S. Kowalczyk, Esej, [w:] Literatura polska XX wieku. Przewodnik encyklopedyczny, red. A. Hutnikiewicz, A. Lam, Warszawa 2000.

${ }^{13}$ Por. R. Sendyka, Nowoczesny esej (część „Czysty Esej”, czyli abstrakcja).

14 G.D. Atkins, Tracing the Essay: Through Experience to Truth, Athens-London 2010 (lokalizację cytatów z tej pracy podaję w tekście głównym). Wzrost zainteresowania „czystym” esejem jest obserwowany w USA od ok. 25 lat. Robert Atwan, wieloletni redaktor serii Best American Essays, przekonuje w tekście z 2012 roku Notes toward the Definition of Essay (w: Essayists on the essay..., s. 197-199), iż ów ruch jest odpowiedzią na wcześniejszą deprecjację eseistyki przez wydawnictwa, krytykę literacką, akademię (gdy ze względu na dominującą przez wiele lat definicję literackości z kręgu New Criticism esej został niejako wykluczony z dziedziny literatury pięknej, przypisano go do kursów creative writing, co zaowocowało znaczną liberalizacją pojmowania gatunku). Do apologetów ambitnej tradycji eseju należą też Ph. Lopate i J. D’Agata. 
rębnione polskie eseje umiejscowione zostaną w skali makro dzięki próbie spojrzenia na nie przez pryzmat ogólnie traktowanego „eseju jako formy”. Owo kanoniczne określenie wzięte $\mathrm{z}$ tytułu metaeseistycznych rozważań Adorna ${ }^{15}$ odznacza się wiele sugerującym zawieszeniem głosu. Możemy dostawić kilka określeń w miejscu brakującego dopełnienia, otrzymując m.in. ujęcie eseju jako formy pisarstwa, poznania czy doświadczania, a listę tych określeń można $\mathrm{z}$ powodzeniem rozwinąć, pozostając w obszarze, diagnozowanego przez Sendykę, antropologicznego ujęcia eseju jako tekstu-podmiotu.

By znaleźć nić przewodnią dla dalszych analiz, można prześledzić pewne miejsca wspólne refleksji o eseju, a jest ich z pewnością wiele. Każde takie miejsce postrzegać da się jako pewne ognisko problemów; raczej jako wiązkę pytań o tożsamym początku niż jako zestaw zbornych odpowiedzi. Obierając opisane wyżej podejście i konfrontując je z określonym zespołem tekstów, można mieć, jak sądzę, nadzieję, iż efektem refleksji nie okaże się spetryfikowany, uproszczony model domniemanej subodmiany gatunkowej, lecz pewna seria ruchomych wariantów eseistycznego projektu, ujmowana za pomocą zestawu cech porównywalnych. Zadanie wydaje się nieco łatwiejsze, gdyż wzięte będą pod uwagę eseje pisane na przestrzeni niespełna 70 lat, odznaczające się nie tylko podobną tematyką i zbliżonym doborem autorytetów ${ }^{16}$, ale też analogicznymi strategiami tekstowymi i tendencjami stylistycznymi.

Punktem wyjścia moich rozważań jest teza, iż odwołania do fotografii i dzieł malarskich pełnią $w$ eseistycznym dyskursie podobne funkcje. Obydwa rodzaje wizualnych przedstawień, choć odmienne w zakresie techniki artystycznej i sposobu utrwalania rzeczywistości, często na równi traktowane są przez piszących jako przedmioty o wielorakim, niestabilnym statusie - dzieła sztuki, dokumentu epoki (czy swobodniej: śladu przeszłości), indywidualnego świadectwa artysty, symbolu napełnianego na drodze reinterpretacji nowymi treściami ${ }^{17}$ albo lustra, w którym przegląda się współczesny widz. Warto dodać, iż w większości wyróżnieni ese-

15 Th.W. Adorno, Esej jako forma, [w:] Sztuka i sztuki. Wybór esejów, przeł. K. Krzemień-Ojak, red. K. Sauerland, Warszawa 1990. Lokalizację przytoczeń z tej pracy oraz z tekstu G. Lukácsa oznaczam, podając nr strony w tekście głównym.

16 Wymienić trzeba P. Muratowa i B. Berensona, ale też J.W. Goethego, Stendhala, J. Ruskina, W. Patera i A. Huxleya (nota bene dwóch ostatnich sformułowało słynne uwagi na temat formy eseju).W przypadku tomu Nowickiego analogiczną tradycję stanowią eseje o fotografii S. Sontag (O fotografii), W. Benjamina (Mała historia fotografii) i R. Barthes'a (Światło obrazu).

17 Np. Karpiński traktuje konkretne obrazy malarskie jako symbole miast, zaś A. Pacholski w Bulwarze cieni (w: Brulion paryski, Kalisz 2001) wykorzystuje słynne zdjęcie Daguerre'a jako symbol odchodzenia w zaświaty. 
iści gustują $\mathrm{w}$ malarstwie figuratywnym lub takim, w którym mimo formy ciążącej ku abstrakcji wyczuwalny jest związek z przedmiotowościąie, zaś Nowicki i Dehnel sięgają do starych zdjęć funkcjonujących w kolekcjonerskim mikroobiegu. Przywoływanie w tekście iluzjonistycznych przedstawień lub tych pobudzających wyobraźnię do poszukiwania związków z rzeczywistością pozaartystyczną okazuje się pretekstem, który zachęca do inicjowania różnego typu poznawczych, czy raczej doświadczeniowych eksperymentów, mających przykładowo na celu wyobraźniowe uczestnictwo w przeszłości (np. Martwa natura $z$ wędzidtem Herberta, Co mówią kamienie Wenecji Bieńkowskiej) lub rozwijanie zmyślonych narracji o osobach z fotografii (Fotoplastikon Dehnela) bądź o słynnych malarzach (Herlinga Sześć medalionów...19). Owo marginalizowanie malarstwa abstrakcyjnego, szczególnie abstrakcji geometrycznej, i fotografii eksperymentalnej przez interesujących mnie autorów daje do myślenia. Zapewne można je tłumaczyć zbieżnością indywidualnych gustów i postaw światopoglądowych, ale warto też zauważyć, iż tego typu oderwana od konkretów sztuka, często oferująca syntetyczne, enigmatyczne formy, wydać się może obca specyfice eseju, szczególnie - „nominalistycznie” zorientowanego Montaigne'owskiego eseju osobistego, a bliższa może raczej wyróżnianemu często jako pewne swoiste zjawisko esejowi filozoficznemu, rozwijanemu na poziomie zaawansowanych abstrakcji (jako przykład można podać Wzniosłość $i$ Awangardę Lyotarda20, gdzie wspomniany jest m.in. czarny kwadrat na białym tle Malewicza). Godne przywołania jest w tym kontekście podejście G. Douglasa Atkinsa, który wprost porównuje esej do rodzajowego malarstwa holenderskiego, zauważając, iż obydwa te fenomeny skupiają się na tym, co przyziemne, i traktują prosty przedmiot jako początek wędrowania - przez zataczanie coraz szerszych kręgów lub niespodziewane uskoki, przeskoki - ku innym obszarom, często coraz poważniejszym, ogólniejszym [68]. Nie sposób nie zauważyć, że odwołania do malarstwa prezentującego z pozoru błahe zjawiska: codzienne sceny, a szczególnie martwe natury ${ }^{21}$ - odnaleźć

18 Zob. przede wszystkim eseje Pollakówny o J. Stajudzie i J. Sempolińskim (Glina $i$ światto, Wrocław 1999).

19 Jednocześnie wyobrażone sceny z życia Caravaggia, Rembrandta i Ribery wpisują te eseje w tradycję Paterowskich imaginary portraits, pośrednio też - portretów B. Micińskiego.

20 J.-F. Lyotard, Wzniosłość i awangarda, przeł. M. Bieńczyk, „Teksty Drugie” 1996, nr $2-3$.

${ }^{21} \mathrm{~Np}$. J. Czapski w martwych naturach doszukiwał się wizji świata poszczególnych malarzy, podobnie Karpiński (Fajka Van Gogha) nazywał martwe natury Van Gogha autoportretami. Herbert (w eseju tytułowym $\mathrm{z}$ tomu Martwa natura $z$ wędzidłem) widział w obrazie Torrentiusa wyraz buntu jednostki niepasującej do mentalności swej epoki; 
można w wielu interesujących mnie tekstach eseistycznych, gdzie zawsze zgłębiane przedstawienia ujawniają swe drugie dno (niesprowadzalne wszakże do konwencjonalnych treści).

Lukács dowodził, iż esej często rozpoczyna od pewnego „zapośredniczającego medium" [89], od rzeczy już uformowanych, przykładowo od obrazów lub dzieł literackich, by niepostrzeżenie przejść do pytań o „ostateczne kwestie życia” [87], nie udzielając przy tym bezpośredniego, jednoznacznego rozwiązania. W tymże rozziewie między pozorną powierzchownością a maksymalistycznymi, nieziszczalnymi zamiarami leżeć miało źródło ironii eseju. Komentując to ujęcie, Atkins zaproponował, by jako ukryte dno eseju postrzegać również uogólnianie pewnych węższych kwestii, np. zjawisk społecznych i kulturowych, ku którym esej wymyka się niepostrzeżenie nie dzięki ironii, a dzięki właściwej mu „przewrotności” (sneakiness) [24-26]. Podobnie Adorno uważał, iż esej łączy to, co „czasowe”, z tym, co „bezczasowe”, i znosi zadekretowane podziały między filozofią pierwszą a filozofią kultury, między doświadczeniem indywidualnym a historycznym [86-87]. Wspomniane perspektywy zebrał Aldous Huxley, który wyróżnił w eseju trzy poziomy (pierwszy to rozważania o konkrecie, drugi - elementy osobistego zaangażowania, trzeci zaś to różnego rodzaju abstrakcyjne uogólnienia) i jako idealny sposób przechodzenia między tymi obszarami wskazał umiejętne oscylowanie między nimi na wzór meandrycznego pisarstwa Montaigne'a ${ }^{22}$. Zbytnie ciążenie ku którejkolwiek z tych tendencji, według Huxleya, oznacza zwykle degenerację eseju (np. przerodzenie się w intymistykę czy impresyjne mówienie wyłącznie o sobie, suchą informacyjność czy akademizm, lub w abstrakcyjną „algebrę" hipostazującą pojęcia i zrywającą z niezapośredniczonym doświadczeniem). W praktyce wyróżnionych przeze mnie autorów pisanie o konkretnych obrazach faktycznie umożliwia postulowane przez Huxleya przejścia, często mogą one zostać zaobserwowane nawet na poziomie pojedynczej ekfrazy. W repertuarze istotnych perspektyw na pewno należałoby wyróżnić po pierwsze spisywanie indywidualnego doświadczenia obrazu i łańcucha prywatnych skojarzeń wywołanych przez malowidło czy fotografię, po wtóre - próby sytuowania określonych dzieł w pewnych kontekstach historycznych i kulturowych, często bardzo odległych od kontekstu źródłowego, przywoływanych na zasadzie porównań ponad epokami (ciekawym przykładem jest wpisywanie przez Zalewskiego doświadczenia obrazów kojarzonych ze złem - Boscha, Goi, Bacona -

J. Pollakówna (Myśląc o obrazach) traktowała przedstawienia Cotána i Chardina jako podszyte mistycyzmem.

${ }^{22}$ A. Huxley, [From the preface to collected essays], [w:] Essayists on the Essay..., s. 89 . 
w kontekst straumatyzowanej mentalności pokolenia Kolumbów). U Ewy Kuryluk ujawnia się też transhistorycznie postrzegana problematyka społeczna: np. jako próba naszkicowania, w dużej mierze dzięki misternym ekfrazom, dziejów dyskryminowanego malarstwa kobiet ${ }^{23}$. Szeroki społeczny kontekst pośrednio przywoływany jest również przez Nowickiego, gdy opisuje on portrety pośmiertne, dokumenty dobroczynności czy zdjęcia w egzotycznych przebraniach. Swobodna eseistyczna komparatystyka wiedzie często do trzeciego istotnego elementu - do przemycania koncepcji o charakterze uniwersalnym (takich jak bardzo pojemna koncepcja sztuki ikonicznej u Olędzkiej-Frybesowej, u Wańka wizja toczącego się aż po współczesność sporu między ikonofilami i ikonoklastami24, u Pacholskiego - związek niektórych nurtów sztuki z manicheizmem, u Bieńkowskiej - „ucieleśnienie ducha” w malarstwie religijnym, u Iwaszkiewicza - stale osłabiany autoironią idealizm estetyczny). Ów wachlarz zagadnień, często powiązanych z krytyką kultury, można uznać za próby określenia roli obrazów jako istotnej części antroposfery, w tym ich związków $\mathrm{z}$ duchowością.

Swobodna wędrówka między tematami to główna zasada kompozycyjna esejów podróżniczych związana bezpośrednio z przemieszczaniem się w przestrzeni ${ }^{25}$. Owa meandryczność toku skojarzeń występuje w wielu innego rodzaju esejach: czasem jako dygresyjność, czasem jako pochodna nieśpiesznego oglądu obrazu przy nieskrępowanym aktywizowaniu ciągu różnorodnych asocjacji, często tych świadczących o znawstwie autora. W ramach typowo eseistycznej erudycyjności wyróżnić należy skłonność do rozwijania erudycji wizualnej (jej znakiem jest już samo „cytowanie”, czyli przywoływanie konkretnych obrazów, ale też zestawianie dzieł różnych twórców, a nawet porównania intermedialne z filmem i fotografią). Podmiot analizowanych esejów ze względu na mnogość aluzji literackich objawia się też jako czytelnik - „the self on the shelf”26, jego skojarzenia wybiegają również często ku muzyce, teatrowi czy architekturze.

Wynikające stąd swoboda i wieloperspektywiczność oglądu, będące składowymi antykonwencjonalnego charakteru eseju, czasem jednak ulegają skrępowaniu, szczególnie gdy dominować zaczynają importowane

${ }^{23}$ E. Kuryluk, Artystki i bęcwaty, [w:] tejże, Art mon amour. Szkice o sztuce, Warszawa 2002.

${ }^{24}$ H. Waniek, Martwa natura z niczym. Szkice z lat 1990-2004, Kraków 2004.

${ }^{25} \mathrm{~K}$. Szalewska ten typ eseistyki opisała jako „pasaże tekstowe” (Pasaż tekstowy. Czytanie miasta jako forma doświadczania przeszłości we wspótczesnym eseju polskim, Kraków 2012).

${ }^{26}$ S. Levine, The self on the shelf, [w:] Essayists on the essay... 
z innych dziedzin, okrzepłe schematy narracyjne, jak opowieść typowo biograficzna o malarzu (bądź Vasariański model „życie i twórczość”), o nurcie malarskim, sprawozdanie z wystawy czy opis galerii. Przymierzanie maski badacza (w przypadku dawnej, anonimowej fotografii będzie to również rola historyka próbującego odtworzyć brakujące dane) czy krytyka sztuki (i to w różnych wydaniach wpływających silnie na styl ekfraz: $\mathrm{w}$ tym zoila czy krytyka-poety), łączące się z inkorporacją pierwiastków nieeseistycznych, przy zestawieniu z projektem idealnej esei-styki niekoniecznie okaże się z nim sprzeczne, potraktowane być może bowiem jako część artystycznego eksperymentu polegającego na celowym „konfrontowaniu różnych dziedzin istnienia"27, najlepiej dzięki umiejętnemu łączeniu odmiennych konwencji i perspektyw jakby na zasadzie „modulacji z tonacji do tonacji”, by tekst przypominał „żywy organizm”28. Artystyczna spójność eseju, przy wewnętrznym bogactwie i pozorach bezładności jest bowiem jednym z nielicznych „wyznaczników” gatunku, co do którego panuje powszechna zgoda komentatorów.

Potencjalnie dezintegrujący charakter owego przymierzania masek często zyskuje przeciwwagę ze względu na niuansowanie retoryki: miast zdecydowanego tonu badacza pojawia się dążący do zaciekawienia czytelnika „opowiadacz”29 (np. u Herberta i Bieńkowskiej) bądź przyjacielski przewodnik po danym miejscu (np. u Herlinga, Olędzkiej-Frybesowej), chętnie przekładający rozciągłość czasową czy przestrzenną na serię misternych ekfraz; ton kategoryczny osłabiany jest przez stosowanie retoryki hipotetycznej, charakterystycznych serii pytań (które wszakże nader często, jak u Pollakówny, zawierają wyraziste implikowane tezy). Nierzadko pierwszoosobowa kreacja podmiotu ustępuje formie pluralis, która wydaje się ambiwalentna: owo „my” da się przecież odczytać jako pozorną bezosobowość instytucji, czasem w wersji apodyktycznej, czasem zaś skromnościowej, na ogół jednak liczba mnoga perswazyjnie buduje wspólnotę z czytelnikiem, włączając go w obręb komunikacji. „Umiejętna oscylacja zaimków"30, czy postulowane przez Woolf uwodzenie czytelnika stylem, tekstowe zaciąganie „zasłony”31, która przygarnie również i odbiorcę, stanowią elementy przystępnej kreacji eseistycznego „ja” jako zajmujacego partnera intymnej rozmowy.

Jedną z najbardziej rozpoznawalnych ról eseisty, czerpiącą swój początek z Prób, jest kreacja dyletanta (niespecjalisty, ale też miłośnika),

27 E. Bieńkowska, dz. cyt., s. 103.

28 A. Huxley, dz. cyt., s. 90.

${ }^{29}$ Z. Herbert, Barbarzyńca w ogrodzie, Warszawa 2004, s. 128.

${ }^{30}$ S. Levine, dz. cyt., s. 161.

${ }^{31}$ V. Woolf, The Modern Essay, [w:] tejże, The Common Reader, London 1948, s. 281. 
której niemalże powszechne eksponowanie urastać może do rangi najłatwiej uchwytnego wykładnika świadomości gatunkowej interesujących mnie autorów. W analizowanym zespole tekstów odnaleźć można pakiet pseudonimów postawy dyletanta: „olśniony troglodyta” (zapożyczony przez Czapskiego od Ciorana), „niefachowiec” (Bieńkowska), „miłośnik” (Herling), „przeciętnie wrażliwe oko”32 (Zalewski), „uparty i naiwny amator" (Herbert; podobnie potraktować można nieco prowokacyjny tytuł Barbarzyńca $w$ ogrodzie). Z tymże wykazem skorelowany jest zasób pejoratywnych określeń badaczy („naukowe mrówki”, „uczeni w piśmie”33), procedur oraz rywalizacji komentatorów („potwór systematyki, duch Linneusza”34; „bzik klasyfikacji”, „jarmark próżności krytyków i historyków sztuki, którzy przekrzykują się nawzajem skłóconymi między sobą sądami”35). Znamienne, iż pojawiająca się tu wyrazista, wręcz hiperbolizowana retoryka antynaukowa (którą wobec współczesnych tendencji w humanistyce ${ }^{36}$ zapewne bezpieczniej byłoby ująć jako antyscjentystyczną, antypozytywistyczną, być może również jako antystrukturalistyczną), jest miejscem wspólnym wskazanych esejów oraz programowych esejów modernistycznych. Według Adorna esej miałby być formą poznania wyemancypowaną od ograniczeń procedur naukowych, sprzeciwiającą się „podziałowi kultury na resorty” [84]. Eseista-dyletant piętnuje przede wszystkim próby przyszpilenia istoty danej twórczości, pojedynczego obrazu przez przypisanie do określonego kontekstu czasoprzestrzennego, do abstrakcyjnych modeli szkół i konwencji. Herbert występuje też przeciwko praktykom analizy formalnej czy ikonograficznej (choć jednocześnie jego eseistyka świadczy o przyswojeniu tej wiedzy). Wyróżnieni autorzy opowiadają się raczej za konkretem i jednostkowością: za oglądem rozpoczynającym od pojedynczego dzieła, i to danego $\mathrm{w}$ indywidualnym doświadczeniu (traktowanym często jako spotkanie ze świadomością malarza ${ }^{37}$ ), wzbogaconego o swobodnie aktywizowane kon-

32 W. Zalewski, Zwiadowcy światta, Warszawa 1999, s. 18.

${ }^{3}$ Z. Herbert, Barbarzyńca $w$ ogrodzie..., s. $71 ; 179$. To drugie określenie zostało powtórzone przez Iwaszkiewicza (Podróże do Włoch, Warszawa 2008, s. 93).

34 Z. Herbert „Mistrz z Delft” $i$ inne utwory odnalezione, red. B. Toruńczyk, Warszawa 2008, s. 55.

${ }^{35}$ G. Herling-Grudziński, Sześć medalionów i srebrna szkatułka, Warszawa 1994, s. 35,90 .

36 Warto wziąć pod uwagę alternatywne koncepcje uprawiania historii sztuki, w tym różne warianty podejścia hermeneutycznego (zob. M. Bryl, Suwerenność dyscypliny. Polemiczna historia historii sztuki od 1970, Poznań 2008, s. 433-486, 580-621).

37 To podejście, przypominające krytykę identyfikującą się (G. Pouleta, J.-P. Richarda, J. Starobinskiego), jest właściwe dla eseistyki Czapskiego czy Fajki Van Gogha Karpińskiego. 
teksty. Eseistycznym ekfrazom zazwyczaj obca jest kreacja rzekomo „czystego" naukowego widzenia, pozornie obiektywnej i stałej perspektywy. Obrazy widziane są w kontekście, np. dzieł sąsiadujących z nimi w galerii, zmącone przez aktualny nastrój odbiorcy, odmiennie odbierane w różnych okolicznościach, o czym wprost pisał Iwaszkiewicz w kontekście oglądania fresku Sąd Ostateczny w Torcello („potężne malowidło, które ma tę właściwość, że o każdej porze dnia inaczej wygląda i o każdej porze roku. A może po prostu odbija usposobienie tego, który nań patrzy, jak w zwierciadle widziałem wtedy jesień moją i smutek mój, a teraz widzę zieloną trawę [...]”38).

Taka kreacja eseisty przypomina common readera Woolf ${ }^{39}$ ze wzglę$\mathrm{du}$ na selekcjonowanie dzieł intrygujących, odbiór dla przyjemności, subiektywny, zapalczywy, czasem pobieżny czy rozwijany na przekór powszechnym gustom ${ }^{40}$, a postępowanie to dotyczy nie tylko recepcji obrazów, ale też recepcji ich omówień: eseiści czerpią bowiem obficie z naukowej i krytycznej literatury przedmiotu, wyławiając koncepcje „pobudzające wyobraźnię"41 czy dosadnie polemizując. Zdarzają się nawet cytaty bez ujawniania źródła. Często odnaleźć można nieprecyzyjne czy anonimowe określenia, jak „niektórzy badacze”, „znawcy”, „historyk”, „krytyk”, aczkolwiek pewne słynne nazwiska uczonych i krytyków powracają przywoływane wprost, gdyż ustanawiają swoisty kod porozumienia, określają „kulturową genealogię"42 (m.in. Burkhardt, Fromentin, a przede wszystkim Berenson). Wyrażenie passionate sightseer ${ }^{43}$, czyli Berensonowska autocharakterystyka, może być zresztą postrzegane jako nazwa kolejnej typowej kreacji eseisty - zmysłowo wrażliwego, zaangażowanego widza. Różnorodność ról podejmowanych przez podmiot eseju z pewnością sprzyja wieloperspektywiczności oglądu, jednocześnie świadcząc o niemożliwości pełnego opisania przedmiotu przy użyciu którejkolwiej wąskiej, specjalistycznej perspektywy. Jak sugeruje E.B. White, wśród wszystkich kreacji osobowych eseisty, wyciąganych z podręcznej garderoby i noszonych niczym kolejne koszule, winien jednak wisieć, ukryty z tyłu „płaszcz Michela de Montaigne, pachnący lekko kam-

38 J. Iwaszkiewicz, dz. cyt., s. 37.

39 Por. G.D. Atkins, dz. cyt., s. 17.

40 Przekorne wybory dyletanta - common readera stanowią chwyt konstrukcyjny eseju Mój wybór z galerii drezdeńskiej Olędzkiej-Frybesowej (w: W głąb labiryntu. Wędrówki po Europie, Kraków 1979).

41 J. Pollakówna, Weneckie tęsknoty, Warszawa 2003, s. 10.

42 Por. E. Bieńkowska, dz. cyt., s. 104.

43 The Passionate Sightseer: From the Diaries by Bernard Berenson, 1947-56, New York 1960. 
forą" 44 , czyli manifestujące swą szczerość, skromne ,ja”, które (a trop ten podsuwa przecież wyraźnie metafora White’a) również jest kwestią obieranego celowo retorycznego kostiumu.

Centralna pozycja ,ja” jako zwornika wypowiedzi to locus communis refleksji o eseju. Jednakże interesujący mnie zespół tekstów jest zróżnicowany pod względem stopnia eksponowania podmiotu (jawnie autobiograficznego czy też rozumianego jako instancja tekstowa). Dominanta autobiograficzna wraz $\mathrm{z}$ bezpośrednią tematyzacją indywidualnego doświadczenia spajają z pewnością pierwszoosobową narrację summae vitae Iwaszkiewicza (Podróźy do Włoch), uwidaczniają się też znacząco u Herberta, Pacholskiego i Karpińskiego. Nawet jeśli otwarcie sygnalizowany podmiot występuje w pozostałych esejach rzadziej czy nawet marginalnie, i w nich ,ja” pełni, fundamentalną według Atkinsa, rolę „gleby”, „laboratorium" [6], w którym rozgrywa się wielopostaciowy eksperyment, w dużej mierze bazujący na wywodzeniu znaczeń $\mathrm{z}$ intymnego doświadczenia obrazów. Owo doświadczenie z pewnością ujawnia się na poziomie licznych ekfraz, które, jak sugerowała Roma Sendyka, pełnią głównie funkcję ekspresywną, stając się lustrem, dzięki któremu ,ja” ogląda siebie i ujawnia swe „funkcje kognitywne”45. Niewątpliwie też rewersem tej strategii autoprezentacji jest swoista perswazyjność zsubiektywizowanych, nierzadko bardzo poetyckich, synestezyjnych ekfraz, mająca wpływać na odbiorcę46.

W ramach eseistycznych opisów wyróżnić można pewne powracające warianty związane $\mathrm{z}$ rozgrywaniem napięć i (częstokroć trudno uchwytnych) przejść między kreowaną na przedrefleksyjną, „wierną" przedmiotowi percepcją zmysłową i podobnie „obiektywną” narratywizacją prezentowanych na obrazie scen a subiektywnym, nierzadko deformującym doświadczeniem i powiązanymi zeń ocenami i refleksjami - czy to misternie przemycanymi, czy to bezpośrednio ujawnianymi. Stopienie wspomnianych aktywności w swojej eseistyce Pollakówna określiła jako „rozmyślające widzenie”47. Naszkicowana siatka przejść nakłada się dodatkowo na kwestie związane $\mathrm{z}$ intermedialną translacją oraz niewysławialnością. Warto przypomnieć, że pojawiające się w tym kontekście serie

${ }^{44}$ E.B. White, [From the foreword to essays of E. B. White], [w:] Essayists on the essay..., s. 105.

${ }^{45}$ R. Sendyka, Esej i ekfraza, s. 58. Zob. też A. Dziadek, Apologia twórczej swobody. Eseje Zbigniewa Herberta: opis - uobecnienie - interpretacja, [w:] Zmyst wzroku, zmyst sztuki. Prywatna historia sztuki Zbigniewa Herberta, red. J.M. Ruszar, cz. 2, Lublin 2006.

46 Zob. D. Lisak-Gębala, „Energia” metafor w ekfrazach eseistycznych, „Pamiętnik Literacki” 2011, z. 3.

47 J. Pollakówna, dz. cyt., s. 6. 
opozycji (dyskursywności i niedyskursywności, konkretności i ogólności, doświadczenia i poznania), zestawione przez Lukácsa ze sporem o uniwersalia, są również nader istotne dla formy eseju. Ekfraza ciążąca ku „obiektywnemu” demonstrowaniu, przekazująca ślad „niemego zapatrzenia"48 rzekomo obywającego się jeszcze bez słów i interpretacji, wprowadza często, wbrew narracyjnej otoczce zwykle podawanej w czasie przeszłym, formę praesens, która nie tylko stanowi typową formę dla opisów unaoczniających (ukrywających werbalne zapośredniczenie w celu „przezroczystego" uobecnienia przedmiotu), ale też sugeruje tekstowe odgrywanie aktualności momentu, w którym ,ja” ogląda obraz. W konstrukcji eseju demonstratywna ekfraza funkcjonuje często jako retardacja, „pauza dla myślenia"49; jako opóźnienie interpretacji lub jej celowe zastąpienie. Przykładem tego ostatniego przypadku może być Herbertowska enumeracyjna deskrypcja obrazu Lorenzettiego, poprzedzona i zwieńczona zastrzeżeniami wobec racjonalnych analiz („Łatwiej to powiedzieć niż wytłumaczyć”; „Halucynacyjna realność przedstawionych przedmiotów jest tak duża, że wątpię, aby jakakolwiek analiza mogła pokusić się o spenetrowanie arcydzieła”). Pięciokrotne powtórzenie słowa ,jest" utwierdza tu spotęgowaną obecność samego malarsko ewokowanego widoku, który mimo to, ze względu na sugestywne metafory, ujawnia się jako przefiltrowany już przez indywidualną percepcję:

Miasto nad morzem - szare mury, zielone domy, czerwone dachy i wieże - zbudowane jest z jasnych form, obrysowanych ściśle diamentową linią. Przestrzeń jest trójwymiarowa [...]. Pejzaż widziany jest z lotu ptaka. Miasto jest puste, jakby wynurzone przed chwilą $\mathrm{z}$ fal potopu. Jest rozżarzone do najwyższego stopnia widzialności i zatopione w bursztynowo-zielonym świetle ${ }^{50}$.

Istotne okazuje się funkcjonowanie ekfraz jako analogicznego do metafory, niedyskursywnego zastępnika pewnej fazy wypowiedzi ${ }^{51}$, często bardzo ozdobnego, wyszukanego stylistycznie, ale też zagadkowego, przykuwającego uwagę. Nawiązania do wizualnych konkretów często sprzyjają przeskokom tematycznym bezpośrednio nieusprawiedliwianym przez autorów i postrzegane być mogą jako zaczątek Adornowskiej „logiki muzycznej, ścisłej a przecież bezpojęciowej sztuki przechodzenia", która, jako przepojona „subiektywnym wyrazem”, przechytrzyć ma „logikę dyskursywną" [98]. Odwołania do obrazów jako przedmiotów, których wewnętrznego bogactwa nie są w stanie wyczerpać jakiekolwiek zestawy

48 W. Zalewski, dz. cyt., s. 16.

49 Tak V. Cunningham określił funkcję ekfraz w powieściach (Why Ekphrasis?, „Classical Philology" 2007, vol. 102, no. 1, s. 60-61).

${ }^{50}$ Z. Herbert, Barbarzyńca w ogrodzie..., s. 86.

51 K. Dybciak, dz. cyt., s. 123. 
pojęć, okazują się nie tylko skorelowane z aktywnościami eseistycznego „ja”, ale też jawią się jako obiekty otwierające nowe, bliższe pozawerbalności, wymiary komunikacji, co zwięźle ujął Karpiński:

[...] utrwalone przez artystów mgnienia ich wewnętrznego świata są ważną pomocą w rozpoznaniu mojego świata. Więcej niż pomocą, stają się jednym z jego składników. Nie tylko mogę dzięki nim przekazać coś innym względnie zrozumiale i bez boleśnie zawiłych obnażeń. Mogę też lepiej rozmawiać ze sobą, dostrzegać siebie i budować siebie ${ }^{52}$.

Podsumowując niniejsze dociekania, można zauważyć, iż udział wizualnych cytatów w artystycznej konstrukcji eseju idzie w parze z ich doniosłą rolą $w$ ramach eseju jako formy poznania i doświadczania. Przywołanie obrazów, będących jakże atrakcyjnymi ready-mades ${ }^{53}$, zarówno narzucającymi swą zmysłową obecność, jak i zanurzonymi w kulturze, jest $\mathrm{w}$ eseistyce nie tylko ozdobą, erudycyjnym cytatem budującym „kulturową genealogię”, konfrontacja z nimi pełni bowiem w tekście, jako zapisywanym „eksperymencie”, istotne funkcje, skorelowane z doświadczeniem i aktywnością poznawczą eseistycznego ,ja”. Różnorako prezentująca się droga od zmysłowej percepcji do indywidualnej prawdy (wiodąca poprzez przywołanie obrazów, często w asyście dodatkowych skojarzeń) jest w interesującej mnie twórczości „re-kreowaniem” doświadczenia $^{54}$ i odtwarzaniem sposobu myślenia ,ja”, swoistą mimikrą procesualnego charakteru tych aktywności ${ }^{55}$. Ich niepowtarzalne konfiguracje przekładane są na jednorazowe „zdarzenie”56 określonego eseju.

52 W. Karpiński, Amerykańskie cienie, Warszawa 2013, s. 64-65.

${ }^{53} \mathrm{~W}$ ten sposób S. Cheeke (Writing for Art: The Aesthetics of Ekphrasis, Manchester 2010, s. 2), tłumaczył niesłabnącą popularność literatury dotyczącej fotografii i malowideł.

54 Zob. komentarz R. Sendyki do koncepcji Adorna (Nowoczesny esej, s. 291).

55 Jako sygnały tej procesualności traktować można imiesłowowe tytuły tomów $P a$ trzac Czapskiego, Myślac o obrazach Pollakówny, Patrzac na ikony Olędzkiej-Frybesowej.

56 O eseju jako „zdarzeniu” zob. R. Sendyka, Nowoczesny esej..., s. 88. 